\title{
Chronic inflammatory cells and damaged limbal cells in pterygium
}

\author{
*Anguria $\mathrm{P}^{1}$, Carmichael $\mathrm{T}^{1}$, Ntuli $\mathrm{S}^{2}$, Kitinya J ${ }^{3}$
}

1. Department of Neurosciences, Division of Ophthalmology, University of the Witwatersrand Johannesburg, South Africa.

2. Department of Community Health, University of Limpopo Polokwane Campus, South Africa

3. Department of Pathology, University of Limpopo Polokwane Campus, South Africa

\begin{abstract}
Background: Chronic inflammation in pterygium occurrence has not been explained. Whether damaged limbal basal epithelial cells are associated with pterygium occurrence in black Africans is not clear.

Objective: To explain chronic inflammation in pterygium, and to clarify whether damaged limbal basal epithelial cells were associated with pterygium occurrence in black Africans.

Methods: Chronic inflammatory changes and damaged limbal basal epithelial cells were assessed in 59 samples.

Results: Chronic inflammatory cells were present in 59 pterygia. Inflammatory cell count in 5 (27.8\%) of 18 small pterygia was $>200$ (high) while in $22(53.7 \%$ ) of 41 large growths was $<200$ (low); $\mathrm{p}=0.25$. The proportion of pterygia with high counts tended to increase with pterygium extent. Twenty (33.9\%) of 59 pterygia recurred after surgery. Ten (50\%) of 20 samples had high cell counts and $10(50 \%)$, low counts; $\mathrm{p}=0.40$.

P53 expression was detected in 11 (18.6\%) of 59 pterygium samples and 5 (71.4\%) of 7 controls; $\mathrm{p}=0.007$. MMP 1 staining was present in $14(23.7 \%)$ of 59 sections and $5(71.4 \%)$ of 7 controls; $\mathrm{p}=0.02$. MMP2 in $16(27.1 \%)$ cases and $5(71.4 \%)$ controls; $\mathrm{p}=0.03$. MMP3 was overexpressed in $16(27.1 \%)$ of 59 cases and $5(71.4 \%)$ controls; $\mathrm{p}=0.03$.

Conclusions: Mild chronic inflammation has a tendency to be more frequent than severe inflammation in pterygia. It is clear that damaged limbal basal epithelial cells are unlikely to be related to pterygium occurrence.
\end{abstract}

Key words: Pterygium, Inflammatory cells

African Health Sciences 2013; 13(3): 725 - 730 http://dx.doi.org/10.4314/ahs.v13i3.29

\section{Introduction}

Ultraviolet light, which is believed to cause pterygium ${ }^{1}$ may induce chronic inflammatory cells in the conjunctiva $^{2}$ or damage limbal stem cells. ${ }^{3}$ Because chronic inflammatory cells were shown to be present in pterygium samples, it was reported that chronic inflammation contributed to pterygium occurrence. ${ }^{4}$ However, there is no report of whether the level of infiltration is related to the severity of inflammation and to pterygium occurrence, or, to pterygium size. In addition, there is no report of whether the degree of inflammatory cell infiltration is related to the grade of fleshiness, pterygium recurrence after surgery, or chronicity of sunlight exposure.

Matrix remodeling may be by matrix metalloproteinases (MMPs) ${ }^{5}$ or due to sunlight. ${ }^{6}$

\begin{tabular}{|l|}
\hline *Corresponding author: \\
Dr. Peter Anguria \\
Department of Neurosciences \\
Division of Ophthalmology \\
University of the Witwatersrand Johannesburg \\
P.O. Box 55226 Polokwane 0700 \\
South Africa \\
Tel +27152676551 \\
E mail irarak58@gmail.com \\
\hline
\end{tabular}

African Health Sciences Vol 13 Issue 3 September 2013
MMPs have been detected in the fibroblasts and stroma of pterygium samples, ${ }^{7}$ suggesting that these MMPs were remodeling the pterygium stroma,${ }^{5}$ but, this was attributed to damaged limbal basal epithelial cells. $^{7}$ Another study did not find MMP expression in the pterygium fibroblasts or stroma yet the limbal basal epithelial cells were damaged. ${ }^{8}$ Whether MMPs are expressed or not by pterygium fibroblasts or stroma has not been corroborated.

Limbal stem cell damage by UV light may manifest as $\mathrm{MMP}^{7,8}$ or $\mathrm{p} 53^{9}$ expression. Although p53 detection rate in pterygium samples may be high, ${ }^{10}$ it has also been reported to be low. ${ }^{11}$ P53 expression in pterygia from black Africans has been reported to be low however, the sample was small. ${ }^{12}$ There is no report of whether or not MMPs are expressed by limbal basal epithelial cells of black African pterygia.

The presence of chronic inflammatory cells in pterygia has not been elucidated and whether the presence of damaged limbal basal epithelial cells is associated or not with pterygium occurrence in black Africans is not clear. Hence, this study was aimed to explain the presence of chronic inflammatory cells in pterygium and to clarify whether the presence of 
damaged limbal basal epithelial cells is associated or not with pterygium occurrence in black Africans. The objectives were to describe the expression of chronic inflammatory cells and damaged limbal basal epithelial cells in pterygium specimens.

This report shows that the degree of chronic inflammatory cell infiltration in pterygium samples tends to be low, and that damaged limbal basal epithelial cells are not likely to be associated with pterygium occurrence.

\section{Methods}

This was a descriptive study of pterygium samples obtained from the patients who were participating in the study on pterygium recurrence after surgery. The pterygia were those that caused corneal astigmatism or obstruction of or threatened to obstruct vision, or caused disfigurement, or were repeatedly irritating. None of the patients had received topical corticosteroids or non-steroidal antiinflammatory treatment before surgery.

Ethical clearance was obtained from the 2 institutional research ethics committees before starting the study and the tenets of the declaration of Helsinki (2000) were followed in obtaining consent.

Fifty nine sections excised $4 \mathrm{~mm}$ from the limbus, that were not fragmented or crushed were selected because trauma can release MMPs into the extracellular space, ${ }^{13}$ which could be mistaken to cause pterygium remodeling. ${ }^{5,7}$ Seven control sections were obtained from the nasal corneo-conjunctiva of patients that were undergoing evisceration for irreparably injured eyes. The lacerations had not extended to the nasal corneo-conjunctiva. We assumed that if damaged limbal basal epithelial cells were associated with pterygium, barely any control would have damaged cells. Chronic inflammatory cells were not investigated in the controls because control eyes were eviscerated more than $72 \mathrm{hrs}$ after injury and this was assumed to allow tissue infiltration with chronic inflammatory cells ${ }^{14}$ thus to confuse the findings. The control patients' selection criteria were similar to those of the pterygium cases. ${ }^{15}$ The sections were marked and laid flat to facilitate orientation as previously reported. ${ }^{7}$

One experienced histotechnologist processed the samples in a standard way. The sections were cut at 3 microns thick from within 300 microns of the mid longitudinal meridian of the pterygia so that the chance of detecting target cells in different specimens was similar. Haematoxylin and eosin $(\mathrm{H}$
\& E) staining was used because it highlights routinely fibroblasts, blood vessels and collagen degeneration (characteristics of pterygium ${ }^{4}$ ), and neoplastic cells. Collagen degeneration served as an objective measure of excessive sunlight exposure. ${ }^{16}$ And neoplastic cells, which may also express $\mathrm{p} 53^{12}$ as well as $\mathrm{MMPs}^{5}$ may be confused with benign damaged cells. ${ }^{7}$

Chronic inflammatory cells were investigated by immunohistochemistry using an antibody against leukocyte common antigen (LCA) and damaged limbal basal epithelial cells, using antibodies against p53 and MMP1, 2 and 3. Extraepithelial MMP expression was studied using the respective antibodies. The antibodies, source and dilutions are shown in table 1 . Standard immunohistochemistry procedures were followed. ${ }^{10}$ The sections were incubated overnight then deparaffinized by xylene. Xylene was removed by decreasing concentrations of alcohol and the specimens washed in distilled water before immersion in target retrieval solution (Diagnostech, Dako, Johannesburg, South Africa). The specimens were treated in a microwave oven then rinsed in Tris Buffered Saline (TBS) (Diagnostech, Dako, Johannesburg, South Africa) before immersion in peroxidase blocking solution (Diagnostech, Dako, Johannesburg, South Africa). The samples were rinsed in TBS and incubated with primary antibodies after-which they were washed in TBS. They were incubated with horseradish peroxidase rabbit/mouse secondary antibody (Diagnostech, Dako, Johannesburg, South Africa) then rinsed in TBS before incubation with 3,3' diamino-benzidinetetrahydrochloride (DAB) chromogen (Diagnostech, Dako, Johannesburg, South Africa). This was followed by incubation with DAB substrate buffer (Diagnostech, Dako, Johannesburg, South Africa). The specimens were bathed in TBS then counterstained with Mayer's haematoxylin. The slides were preserved using standard histological methods. One experienced and masked Pathologist $(\mathrm{JK})$ read the slides. 
Table 1: Antibodies used and their dilutions

\begin{tabular}{llll}
\hline Antibody & Clone & Source & Dilution \\
\hline LCA & PD7/26 and 2B11 & Dako & $1: 50$ \\
P53 & DO-7 & & \\
MMP1 & 3B6 & Santa Cruz & \\
MMP2 & $8 B 4$ & & \\
MMP3 & 1B4 & & \\
\hline
\end{tabular}

\section{Data analysis}

Cells expressing LCA were counted and the count compared in all pterygia, and in samples of pterygia that recurred. Trends were examined. Trends in the expressions of p53 and MMPs were also examined. The trends or deviations from expected trends indicated significance.

Statistical significance was tested by the Fisher's exact test and $\mathrm{p}<0.05$ was considered to be significant. Statistical calculations were done using STATA 9 for Windows software (STATA Corporation, College Station, USA).

\section{Results}

Fifty nine pterygia were investigated by immunohistochemistry. Forty five were from females while 14, from males. The patients' age range was from 23-64 years. Thirty three $(55.9 \%)$ of 59 individuals were $<50 \mathrm{yrs}$ old (young individuals ${ }^{17}$ ) while $26(44.1 \%)$ were $>50 \mathrm{yrs}$ old (old persons ${ }^{17}$ ). Spectacles or sunglasses had not been used. All pterygia were opaque. Neoplasia was confirmed absent, and fibroblasts and blood vessels were identified in $59(100 \%)$ specimens. Collagen degeneration was absent in one $(1.7 \%)$ of 59 specimens.

LCA positive cells were found to be scattered unevenly in all samples. These cells were located mainly in the stroma and away from the superficial epithelial cells (figure1). Intravascular cell expression of LCA was not considered. Eighteen $(30.5 \%)$ of 59 pterygia were grade 2 (small) and 41 $(69.5 \%),>$ grade 3 (large). The inflammatory cell count in $5(27.8 \%)$ of 18 small pterygia was $>200$ (high) and in $22(53.7 \%)$ of 41 large pterygia, was $<200$ (low); $\mathrm{p}=0.25$ Fisher's exact test. The proportion of samples with high cell counts had a tendency to increase with pterygium extent. Twenty $(33.9 \%)$ of 59 pterygia recurred after surgery. Ten $(50 \%)$ of 20 samples had high cell counts and 10 $(50 \%)$, low counts; $\mathrm{p}=0.40$ Fisher's exact test.

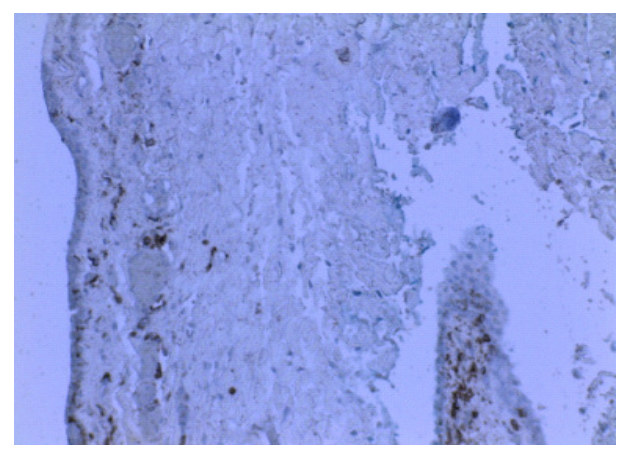

Figure 1: Photomicrograph of a pterygium section immunostained with LCA showing scattered brown reaction product indicating the presence of chronic inflammatory cells X200

Figure 2 shows MMP1, 2 and 3 cytoplasmic immunereaction product of limbal basal epithelial cells. A similar result was obtained in the positive controls. MMP 1 was present in $14(23.7 \%)$ of 59 pterygium sections, and $5(71.4 \%)$ of 7 controls; $p=0.02$ Fisher's exact test. MMP2 in $16(27.1 \%)$ cases, and $5(71.4 \%)$ controls; $\mathrm{p}=0.03$ Fisher's exact test. MMP3 was overexpressed in $16(27.1 \%)$ of 59 cases, and 5 $(71.4 \%)$ of 7 controls; $p=0.03$ Fisher's exact test. MMPs were not detected in fibroblasts or stroma of pterygia or controls.

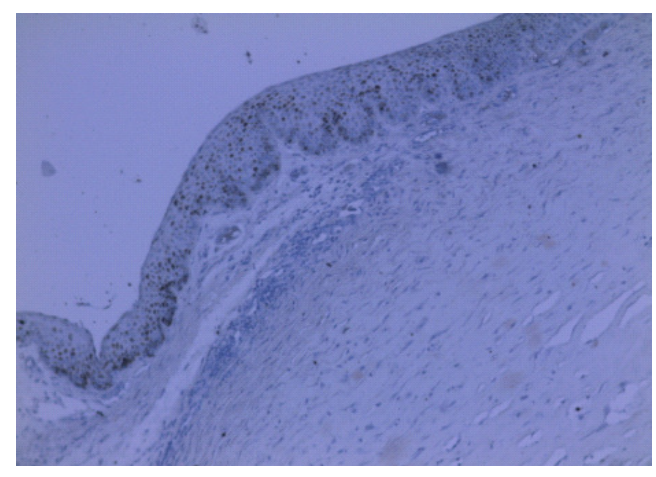

Figure 2: Section of pterygium at limbus. Immunostaining with an antibody against MMP1. Basal cytoplasmic brown reaction product was found indicating a positive result. X100. A similar result was obtained for MMP2, 3 , and the respective controls (images not shown). 
Figure 3 shows limbal basal epithelial nuclearimmunostaining with p53 antibody. A similar result was obtained in the controls. P53 was detected in 11 $(18.6 \%)$ of 59 pterygium samples, and $5(71.4 \%)$ of 7 controls; $p=0.007$ (Fisher's exact test). MMP and p53 expressions were co-localised in 10 (90.9\%) of 11 p53 positive pterygium samples.

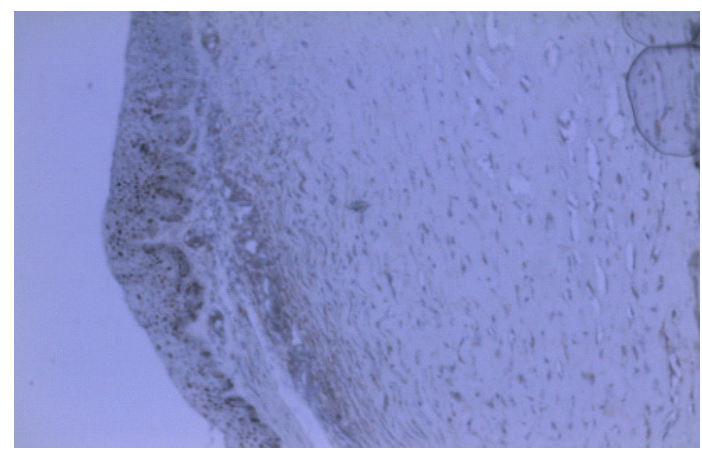

Figure 3: Section of pterygium at limbus. Immunostaining with p53 antibody. Brown reaction product was found in the nuclei of basal cells indicating accumulation of p53 protein. X100. A similar result was obtained in the limbus of controls (image not shown)

\section{Discussion}

Leukocyte common antigen has been used to identify $\mathrm{T}$ lymphocytes in conditions of persistent inflammation. ${ }^{18}$ However, LCA is also present in lymphocytes whether involved in antigen/antibody reaction at an epithelial surface, ${ }^{19}$ or, lymphoma. ${ }^{20}$ Because LCA positive cells were located in the stroma and away from the surface epithelial cells, and were scattered rather than in masses, it is most likely that LCA positive cells in the present study indicate chronic pterygium inflammation ${ }^{4}$ other than ocular surface hypersensitivity reactions ${ }^{19}$ or conjunctival lymphoma. ${ }^{20}$

Although the inflammatory cell count was correlated with pterygium extent, the cell count clearly indicates severity of inflammation rather than pterygium extent because some small growths had high counts while some large ones had low counts. As the majority (59\%) of the samples had low cell counts this suggests that inflammation may not be crucial for pterygium to be present or to be opaque. In addition, chronic pterygium inflammation appears not to be important for pterygium to recur after surgery, which is consistent with a previous report. ${ }^{17}$ It looks as if the severity of chronic inflammation is independent of the degree of exposure to sunlight because some pterygia with collagen degeneration had high cell counts, while others also with collagen degeneration had low counts. These observations seem to be consistent with a previous report that showed that the severity of expressed proinflammatory cytokines varied between pterygia exposed to ambient light. ${ }^{21}$ The apparent independence of the severity of inflammation, independent of the level of exposure suggests that an intrinsic determinant of the degree of inflammation possibly exists.

Some individuals may be deficient of Tlymphokine activated killer cell-originated protein kinase (TOPK) and its deficiency appears to intensify sunlight induced inflammation. ${ }^{22}$ This would seem to suggest that a hereditary predisposition may be the reason that inflammation was severe in some pterygia.

Failure to detect MMP expression in fibroblasts or stroma contradicts a previous report, ${ }^{7}$ perhaps due to persistent exposure to sunlight without wearing spectacles which may reduce UV radiation reaching the eyes. ${ }^{23} \mathrm{UV}$ light induces proinflammatory cytokines $^{21,24}$ and growth factors ${ }^{24}$ in the conjunctiva. In the setting of inflammation, fibroblasts synthesize collagen rather than secrete MMPs moreover, transforming growth factor-beta inhibits MMPs. ${ }^{14}$ Lack of MMP expression in fibroblasts or stroma shows that matrix remodeling observed in pterygia is unlikely to be due to MMPs. Rather, it is possibly due to sunlight damage. ${ }^{6,16}$

This study has shown that damaged limbal stem cells are not a factor in pterygium occurrence, which is also reported by Tsai et al. ${ }^{11}$ However the study by Pelit et al showed the contrary. ${ }^{10}$ We think this may be because damaged limbal stem cells are not being eliminated by natural killer cells. ${ }^{25}$ Immunodeficiency would impair NK cells thereby increasing the expression of damaged cells. ${ }^{26}$

\section{Conclusions}

The inflammatory cell count in pterygia shows severity of inflammation. Mild inflammation tends to be more frequent than severe inflammation. Pterygium inflammation seems to have no relationship with pterygium recurrence after surgery. It is clear that inflammation occurs in the setting of sunlight exposure without UV protection. However, the degree of inflammation seems not to be controlled by the duration of sunlight exposure. Pterygium occurrence obviously, is not linked to damaged limbal basal epithelial cells. 


\section{Acknowledgements}

The antibodies and reagents used were provided by the oral pathology laboratory which is used for research at Polokwane Hospital. We thank $\mathrm{Mr}$ Mashishi DB for performing laboratory tests.

\section{References}

1. Nemesure B, Wu S-Y, Hennis A, Leske MC, Barbados Eye Studies Group. Nine-Year Incidence and Risk Factors For Pterygium in the Barbados Eye Studies. Ophthalmology 2008; 115: 2153-2158.

2. Gaton DD, Lichter H, Avisar I, Slodovinic D, Solomon AS. Lymphocytic reaction to ultraviolet radiation on rabbit conjunctiva. Ann Ophthalmol (Skokie). 2007; 39: 128-33.

3. Tseng SCG, Lee S-B and Li D-Q. Limbal stem cell deficiency in the pathogenesis of pterygium. In: PTERYGIUM edited by Hugh R Taylor. 2000 Kugler Publications, The Hague, The Netherlands. ISBN 9062791742.

4. Hill JC, Maske R. Pathogenesis of pterygium. Eye 1989; 3: 218-226.

5. Jiang Y, Goldberg ID, Shi YE. Complex roles of tissue inhibitors of metalloproteinases in cancer. Oncogene 2002; 21: 2245-2252.

6. Kato S, Aoshima H, Saitoh Y, Miwa N. FullereneC60/liposome complex: Defensive effects against UVA-induced damages in skin structure, nucleus and collagen type I/IV fibrils, and the permeability into human skin tissue. Journal of Photochem and Photobiol B: Biol. 2010; 98: 99-105.

7. Dushku N, John MK, Shultz GS, Reid TW. Pterygia Pathogenesis: corneal invasion by matrix metalloproteinase expressing altered limbal epithelial basal cells. Arch Ophthalmol. 2001; 119: 695-706.

8. Di Girolamo N, McCluskey P, Lloyd A, Coroneo MT, Wakefield D. Expression of MMPs and TIMPS in Human Pterygia and Cultured Pterygium Epithelial Cells. Invest Ophthalmol Vis Sci. 2000; 41: 671-679.

9. Dushku N, Reid TW. P53 expression in altered limbal cells of pingueculae, pterygia and limbal tumors. Curr Eye Res 1997; 16: 1179-92.

10. Pelit A, Bal N, Akova YA, Demirhan B. P53 expression in pterygium in two climatic regions in Turkey. Indian J Ophthalmol. 2009; 57: 203-206.

11. Tsai YY, Chang KC, Lin CL, et al. p53 Expression in pterygium by immunohistochemical analysis: a series report of
127 cases and review of literature. Cornea 2005; 24: 583-6.

12. Ateenyi-Agaba C, Dai M, LeCalvez F. TP53 mutations in squamous-cell carcinomas of the conjunctiva: evidence for UV-induced mutagenesis. Mutagenesis 2004; 19: 395-401.

13. Mulholland B, Tuft SJ, Khaw PT. Matrix metalloproteinase distribution during early corneal wound healing. Eye 2005; 19: 584-588.

14. Mitchell RN, Cotran RS. Acute and chronic inflammation; tissue repair: cell regeneration and fibrosis in: ROBBINS BASIC PATHOLOGY $7^{\text {th }}$ edition $2002 ; 33-78$. SAUNDERS. An imprint of ELSEVIER.

15. Anguria P, Ntuli S, Interewicz B, Carmichael T. Traditional eye medication and pterygium occurrence in Limpopo Province. S Afr Med J. 2012; 102: 687-690.

16. Bae JY, Choi JS, Kang SW, Lee YJ, Park J, Kang YH. Dietary compound ellagic acid alleviates skin wrinkle and inflammation induced by UV-B irradiation. Exp Dermatol. 2010; 19:e 182-90.

17. Chen PP, Ariyasu RG, Kaza V, Labree LD, McDonnell PJ. A Randomized Trial Comparing Mitomycin C and Conjunctival Autograft After Excision of Primary Pterygium. Am J Ophthalmol 1995; 120: 151-160.

18. Binnebosel M, Rosch R, Junge K, Lynen-Jansen $\mathrm{P}$, Schumpelick V, Klinge U. Macrophage and T-lymphocyte infiltrates in human peritoneal adhesions indicate a chronic inflammatory disease. World J Surg 2008; 32: 296-304.

19. Saltini C, Kirby M, Trapnell BC, Tamura N, Crystal RG. Biased accumulation of $\mathrm{T}$ lymphocytes with "memory"-type CD45 leukocyte common antigen gene expression on the epithelial surface of the human lung. J Exp Med 1990; 171: 1123-40.

20. Al-Muammar A, Hodge WG, Farmer J. Conjunctival T-cell Lymphoma: A Clinicopathologic Case Report. Ophthalmology 2006; 113: 459-61.

21. Di Girolamo N, Kumar RK, Coroneo MT, Wakefield D. UVB-Mediated Induction of Interleukin-6 and -8 in Pterygium Epithelial Cells. Invest Ophthalmol Vis Sci. 2002; 43: 3430-3437.

22. Li S, Zhu P, Zykova T, et al. T-LAK celloriginated protein kinase (TOPK) Phosphorylation of MKP1 Protein Prevents Solar Ultraviolet light-induced Inflammation through Inhibition of the p38 Protein Signaling Pathway. J Biol Chem 2011; 286: 29601-9. 
23. Rosenthal FS, Bakalian AE, Taylor HR. The effect of prescription eyewear on ocular exposure to ultraviolet radiation. Am J Public Health 1986; 76 : 1216-1220.

24. Kria L, Ohira A, Amemiya T. Immunohistochemical localization of basic fibroblast growth factor, platelet derived growth factor, transforming growth factor-â and tumor necrosis factor-á in the pterygium. Acta histochem (Jena) 1996; 98: 195-201.
25. Tang KF, Ren H, Cao J, et al. Decreased Dicer expression elicits DNA damage and upregulation of MICA and MICB. J Cell Biol 2008; 182: 233-9.

26. Mavillo D, Lombardo G, Benjamin J, Kim D, Follman D, et al. Characterization of CD56-/ CD16+ natural killer (NK) cells: A highly dysfunctional NK subset expanded in HIVinfected viremic individuals. Proc Natl Acad Sci USA 2005; 102: 2886-2891. 